\title{
Effectiveness of Common Fish Screen Materials for Protecting Lamprey Ammocoetes-Influence of Sweeping Velocities and Decreasing Flows
}

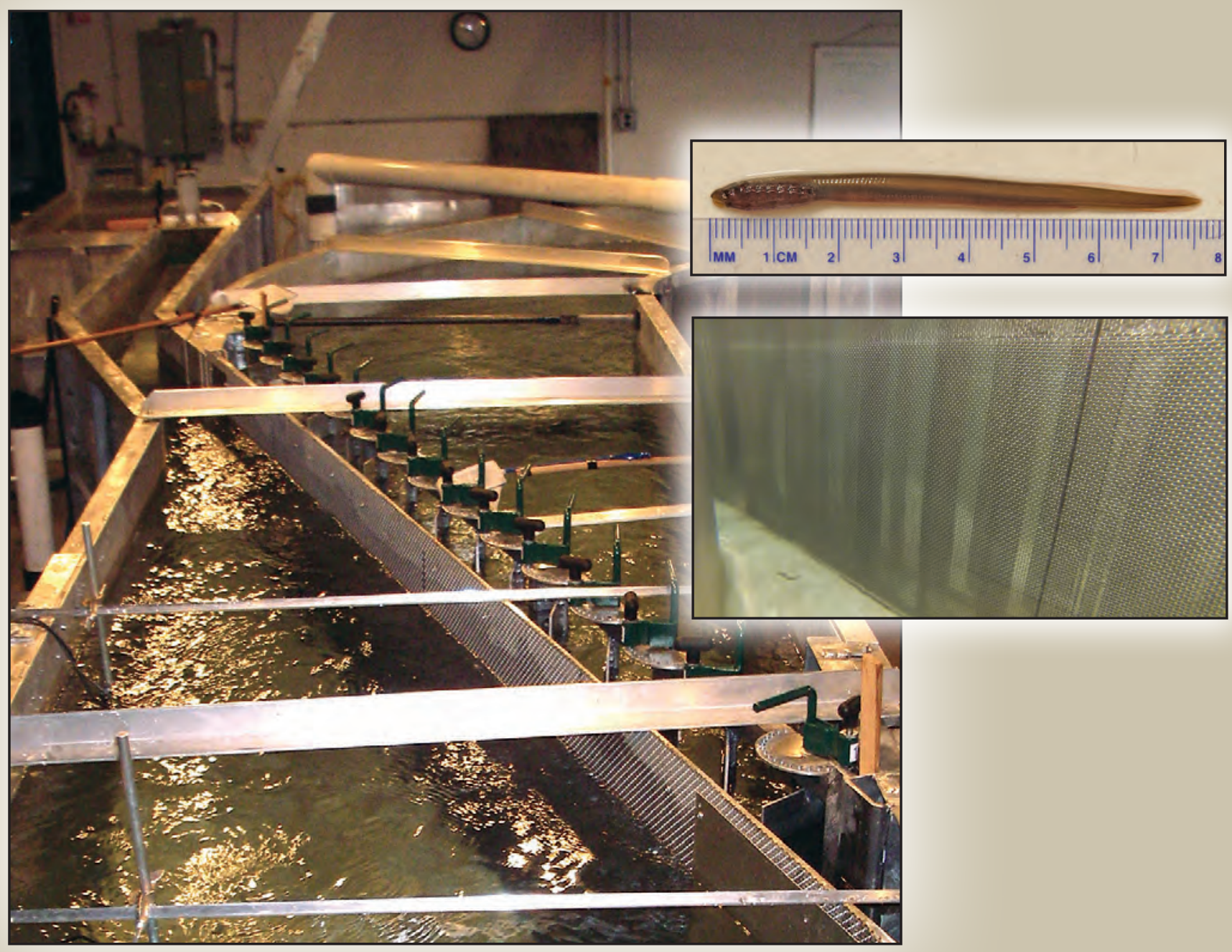

Open-File Report 2017-1163 
Background image: Large oval flume. Photograph by Lisa Weiland, U.S. Geological Survey, March, 11, 2014.

Top right: Lamprey ammocoete lined up against ruler. Photograph by Lisa Weiland, U.S. Geological Survey, August 11, 2015.

Bottom right: Lamprey ammocoete on bottom of flume, entering bypass channel. Photograph by Lisa Weiland, U.S. Geological Survey, April, 8, 2014. 


\section{Effectiveness of Common Fish Screen Materials for Protecting Lamprey Ammocoetes-Influence of Sweeping Velocities and Decreasing Flows}

By Matthew G. Mesa, Theresa L. Liedtke, Lisa K. Weiland, and Helena E. Christiansen

Open-File Report 2017-1163

U.S. Department of the Interior

U.S. Geological Survey 


\section{U.S. Department of the Interior \\ RYAN K. ZINKE, Secretary}

\section{U.S. Geological Survey \\ William H. Werkheiser, Deputy Director \\ exercising the authority of the Director}

U.S. Geological Survey, Reston, Virginia: 2017

For more information on the USGS-the Federal source for science about the Earth, its natural and living resources, natural hazards, and the environment-visit https://www.usgs.gov/ or call 1-888-ASK-USGS (1-888-275-8747).

For an overview of USGS information products, including maps, imagery, and publications, visit https:/store.usgs.gov.

Any use of trade, firm, or product names is for descriptive purposes only and does not imply endorsement by the U.S. Government.

Although this information product, for the most part, is in the public domain, it also may contain copyrighted materials as noted in the text. Permission to reproduce copyrighted items must be secured from the copyright owner.

Suggested citation:

Mesa, M.G., Liedtke, T.L., Weiland, L.K., and Christiansen, H.E., 2017, Effectiveness of common fish screen materials for protecting lamprey ammocoetes-Influence of sweeping velocities and decreasing flows: U.S. Geological Survey Open-File Report 2017-1163, 19 p., https://doi.org/10.3133/ofr20171163.

ISSN 2331-1258 (online) 


\section{Contents}

Abstract

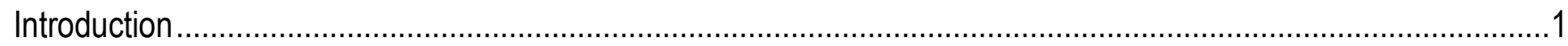

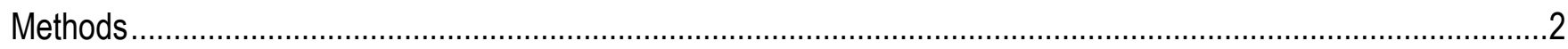

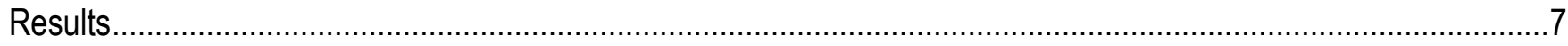

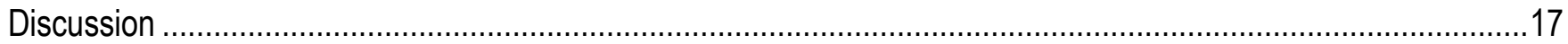

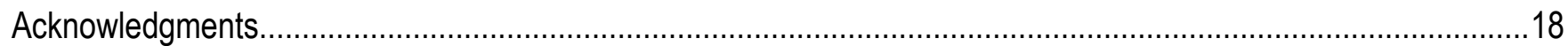

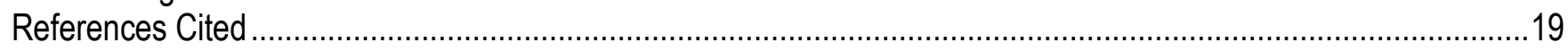

\section{Figures}

Figure 1. Schematic of test flume used to test the effectiveness of common screen materials for protecting lamprey ammocoetes.

Figure 2. Approach velocity and sweeping velocity measurements for four screen types at three water depths for a target AV of 12 centimeters per second

Figure 3. Approach velocity (AV) and sweeping velocity measurements for four screen types at three water depths for a target AV of 6 centimeters per second......

Figure 4. Length frequency distributions of lamprey ammocoetes used for entrainment and impingement tests at two approach and sweeping velocities with four screen materials.

Figure 5. Number of lamprey ammocoetes that were entrained, not entrained, or escaped from the screen surface during tests of four screen materials

Figure 6. Amount of time it took for a fish to reach the bypass either by passing along the screen face or swimming freely in the flume or the amount of time it took for the fish to become entrained

Figure 7. Logistic regression showing the entrainment probability for lamprey ammocoetes of various lengths exposed to four screen materials at an approach velocity of 12 centimeters per second and a sweeping velocity of 35 centimeters per second.

Figure 8. Logistic regression showing the entrainment probability for lamprey ammocoetes of various lengths exposed to three screen materials at an approach velocity of 6 centimeters per second and a sweeping velocity of 18 centimeters per second.

Figure 9. Length frequency distributions of ammocoetes impinged and not impinged on four screen materials at an approach velocity of 12 centimeters per second and a sweeping velocity of 35 centimeters per second ....... 15 Figure 10. Length frequency distributions of ammocoetes impinged and not impinged on four screen materials at an approach velocity of 6 centimeters per second and a sweeping velocity of 18 centimeters per second

\section{Tables}

Table 1. Descriptive statistics of flume hydraulic conditions and lamprey ammocoetes tested for entrainment with four screen materials

Table 2. Impingement statistics for four screen materials at two approach velocities. 


\section{Conversion Factors}

International System of Units to U.S. customary units

\begin{tabular}{lll}
\hline \multicolumn{1}{c}{ Multiply } & By & \multicolumn{1}{c}{ To obtain } \\
\hline centimeter $(\mathrm{cm})$ & Length & \\
millimeter $(\mathrm{mm})$ & 0.3937 & inch (in.) \\
meter $(\mathrm{m})$ & 0.03937 & inch (in.) \\
\hline & 1.094 & yard (yd) \\
\hline liter per minute $(\mathrm{L} / \mathrm{min})$ & Flow & \\
\hline & 0.2641 & gallons per min (gal $/ \mathrm{min})$ \\
\hline centimeter per second $(\mathrm{cm} / \mathrm{s})$ & Velocity & \\
\hline
\end{tabular}




\title{
Effectiveness of Common Fish Screen Materials for Protecting Lamprey Ammocoetes-Influence of Sweeping Velocities and Decreasing Flows
}

\author{
By Matthew G. Mesa, Theresa L. Liedtke, Lisa K. Weiland, and Helena E. Christiansen
}

\begin{abstract}
In previous tests of the effectiveness of four common fish screen materials for excluding lamprey ammocoetes, we determined that woven wire (WW) allowed substantially more entrainment than perforated plate (PP), profile bar (PB), or Intralox (IL) material. These tests were simplistic because they used small vertically-oriented screens positioned perpendicular to the flow without a bypass or a sweeping velocity (SV). In the subsequent test discussed in this report, we exposed ammocoetes to much larger (2.5-m-wide) screen panels with flows up to $10 \mathrm{ft}^{3} / \mathrm{s}$, a SV component, and a simulated bypass channel. The addition of a SV modestly improved protection of lamprey ammocoetes for all materials tested. A SV of $35 \mathrm{~cm} / \mathrm{s}$ with an approach velocity (AV) of $12 \mathrm{~cm} / \mathrm{s}$, was able to provide protection for fish about $5-15 \mathrm{~mm}$ smaller than the protection provided by an AV of 12 $\mathrm{cm} / \mathrm{s}$ without a SV component. The best-performing screen panels (PP, IL, and PB) provided nearly complete protection from entrainment for fish greater than 50-mm toal length, but the larger openings in the WW material only protected fish greater than 100-mm total length. Decreasing the AV and SV by 50 percent expanded the size range of protected lampreys by about 10-15 $\mathrm{mm}$ for those exposed to IL and WW screens, and it decreased the protective ability of PP screens by about $10 \mathrm{~mm}$. Much of the improvement for IL and WW screens under the reduced flow conditions resulted from an increase in the number of lampreys swimming away from the screen. Fish of all sizes became impinged (that is, stuck on the screen surface for more than $1 \mathrm{~s}$ ) on the screens, with the rate of impingement highest on PP (3972 percent) and lowest on WW (7-22 percent). Although impingements were common, injuries were rare, and 24-h post-test survival was greater than 99 percent. Our results refined the level of protection provided by these screen materials when both an AV and SV are present and confirmed our earlier recommendation that WW screens be replaced with more effective materials. Future work should focus on determining the risks associated with other screen types (for example, rotary drum screens, horizontal flat plate screens) and exploring the effectiveness of higher SV:AV ratios, because it may help expand the range of sizes protected by the best performing materials.
\end{abstract}

\section{Introduction}

Water diversions and screens are sources of entrainment (unintended diversion into an unsafe passage route), injury, and mortality of fish. The larval and juvenile life stages of lampreys may be particularly vulnerable to screening effects because of their small size, unique morphology, and poor swimming performance (Dauble and others, 2006; Lampman and Beals, 2014). Although no currently available screen material can completely eliminate the risk of lamprey entrainment (Lampman and others, 2014), screen size and material play a clear role (Rose and Mesa, 2012). Previously, we tested 
the effectiveness of four common fish screen materials for excluding lamprey ammocoetes and found that woven wire (WW) material allowed substantially more entrainment (that is, passage through the screen) than perforated plate (PP), profile bar (PB), or Intralox (IL) material (Rose and Mesa, 2012). However, these tests were simplistic and probably a worst-case scenario for lamprey ammocoetes because they used small pieces of vertically-oriented screen material positioned perpendicular to the flow without a bypass route or a sweeping velocity (SV, the velocity of water flowing parallel to the screen surface). For this work, we increased the ecological realism of the tests done by Rose and Mesa (2012) to further explore the potential effects of irrigation diversion screens on ammocoetes. We designed and built a large, recirculating flume that could hold a 2.5-m-wide screen panel at an angle to the flow which could be controlled up to a maximum of $10 \mathrm{ft}^{3} / \mathrm{s}$. With this device, we could alter the screen angle, flow rate, approach and sweeping velocities, and provide fish with a simulated bypass channel. We used the same screen materials used in the previous tests to evaluate larval lamprey passage, including entrainment risk, passage time, and impingement frequency and duration at two water velocities for each screen type. Our goal was to determine the suitability of salmonid fry-based screening criteria for protecting larval lampreys and to identify which screen materials provided the best protection for these unique fish.

\section{Methods}

We collected larval lamprey (hereinafter "ammocoetes") from Gibbons Creek, Washington, and from Herman Creek, Oregon, using electrofishing and sediment grab samples in 2010, 2012, and 2013. We also obtained test fish from the Yakima Nation Prosser Fish Hatchery in Prosser, Washington (fish originally salvaged from diversions within the Yakima Basin). Ammocoetes were presumed to be Pacific lamprey (Entosphenus tridentatus), though Western brook lampreys (Lampetra richardsoni) also reside in similar habitat and are difficult to distinguish from Pacific lamprey ammocoetes. We did not verify their identity. To reduce the effect on local fish populations, we also spawned adult Pacific lampreys in our laboratory (Cook, Washington) in June 2012 and reared their offspring using protocols adapted from Meeuwig and others (2005). Laboratory-spawned Pacific lampreys and small wild ammocoetes were held in rectangular fiberglass tanks $(51 \times 43 \times 27 \mathrm{~cm}$ [length by width by depth] $)$. Large wild ammocoetes collected in 2010 were held in a long rectangular fiberglass tank $(208 \times 56 \times 53$ $\mathrm{cm})$. Each tank contained beach sand for burrowing substrate based on the size of the fish, with a depth of approximately $5 \mathrm{~cm}$ for wild ammocoetes and approximately $2.5 \mathrm{~cm}$ for laboratory-spawned ammocoetes. Tanks were provided a simulated natural photoperiod with overhead incandescent lights and supplied with sand-filtered water $(1.5 \mathrm{~L} / \mathrm{min}$ for all tanks except the tank with large wild ammocoetes, which had a flow of $7 \mathrm{~L} / \mathrm{min}$ ) from the Little White Salmon River, Washington. Water temperature during normal rearing ranged from 5.0 to $8.5^{\circ} \mathrm{C}$ and increased by $2-3{ }^{\circ} \mathrm{C}$ during some days when fish were fed with the inflow water off. Fish were fed a slurry of active yeast and commercial fry food (Gemma Wean 0.1; Skretting, Vancouver, British Columbia) using methods modified from Rose and Mesa (2012).

To test ammocoete interactions with different screen materials, we designed a large, aluminum oval flume and installed an angled screen panel in a straight section of the flume (fig. 1). We used a Flygt 4610 submersible mixer (Xylem Water Solutions, Sundbyberg, Sweden) controlled by an Altivar 61 variable speed drive (Schneider Electric, Rueil Malmaison, France) to generate flow around the flume and installed a turning vane to straighten the flow of water around the end of the flume upstream of the screen. We installed screen panels at a $20^{\circ}$ angle to the flow and controlled flow through the screen using a row of baffles immediately behind the screen. About 92 percent of the flow passed through the screen; the remaining 8 percent was directed into a bypass channel and flowed over a $69 \mathrm{~cm}$ 
high ramp into a bypass tank. Water was pumped from the bypass tank with a 7.5 horsepower centrifugal pump and returned to the flume downstream of the mixer, thus creating a recirculating flow. We used a variable speed drive to control the pump speed and we measured pump flow with an in-line paddle wheel flow meter (model 9002 Midwest Instruments and Controls, Sterling Heights, Michigan), which we mounted on the bypass water return pipe.

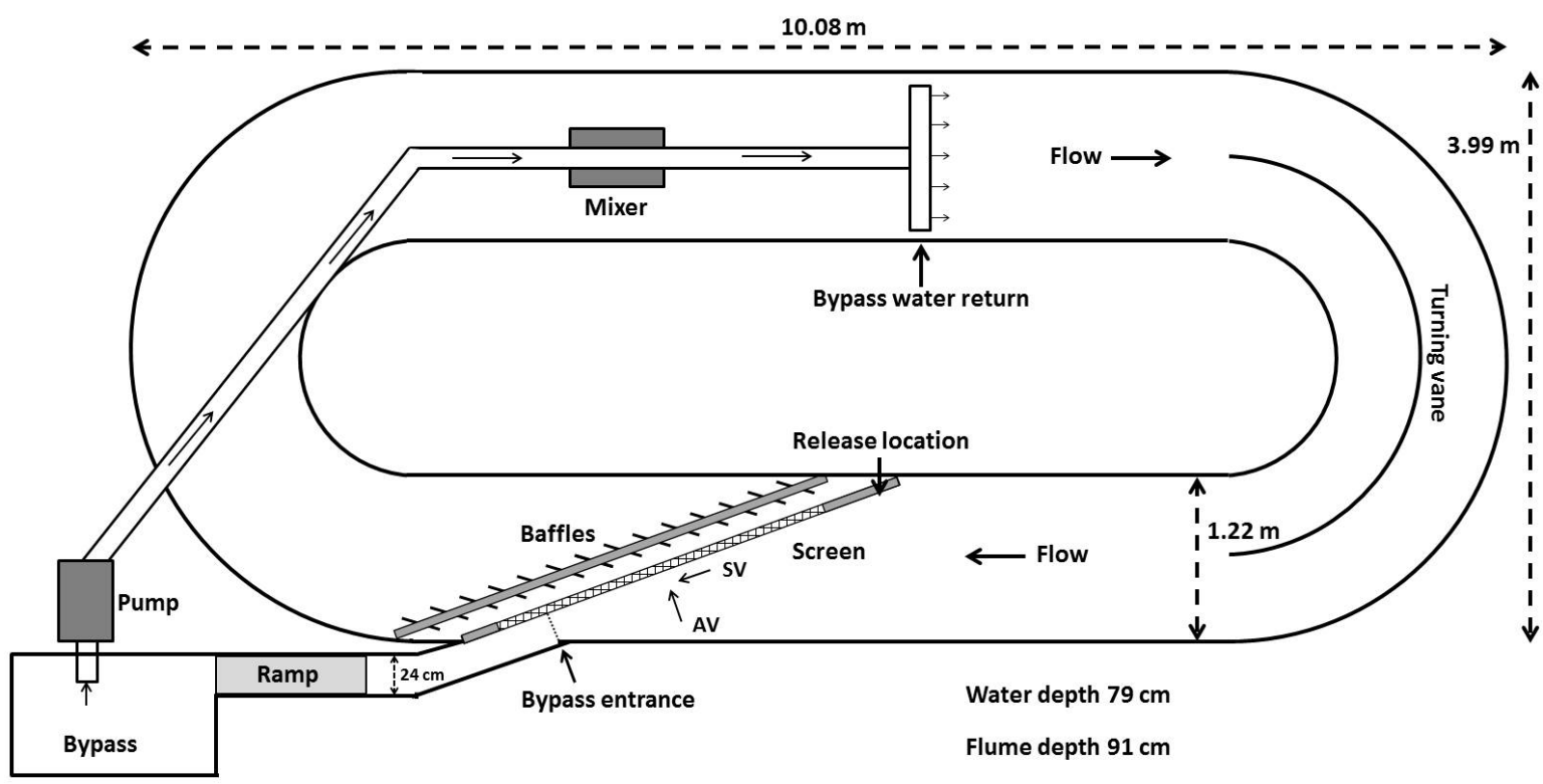

Figure 1. Schematic of test flume used to test the effectiveness of common screen materials for protecting lamprey ammocoetes.

We tested the following screen materials:

1. Perforated plate with $2.38-\mathrm{mm}$ round holes and 27 percent open area;

2. Intralox engineered polymer screen (www.hydrolox.com) with an opening size of $1.7 \times 19.1 \mathrm{~mm}$ and 32 percent open area;

3. 12-gauge woven wire with 3.68-mm square openings and 33.6 percent open area; and

4. Profile bar (www.hendrickscreenco.com) with 1.75-mm slot opening and 42 percent open area.

The woven wire is an older screen material in use at some screening facilities but not used in new screen construction because of its large openings. It was included in testing as an anticipated worstcase scenario screen material for lamprey ammocoetes. For each screen test, we adjusted mixer, pump, and baffle settings to generate an approach velocity (AV, water velocity perpendicular to the screen face) of about 12 or $6 \mathrm{~cm} / \mathrm{s}$ and a SV of about three times the AV (35 or $18 \mathrm{~cm} / \mathrm{s})$ over the entire screen face. To establish our target AV and SV values, we first set the mixer and pump to achieve a discharge appropriate for the total screen surface area (about $2.51 \times 0.78 \mathrm{~m}, \mathrm{~L} \times \mathrm{D}$, or $1.96 \mathrm{~m}^{2}$ ) using the formula 


$$
\mathrm{Q}=\mathrm{A} \times \mathrm{V}
$$

where

$$
\begin{aligned}
& \mathrm{Q}=\text { total flow or discharge in } \mathrm{m}^{3} / \mathrm{s} \\
& \mathrm{A}=\text { surface area of the screen panel, and } \\
& \mathrm{V}=\text { target } \mathrm{AV} \text { (either } 12 \text { or } 6 \mathrm{~cm} / \mathrm{s} \text { ). }
\end{aligned}
$$

Total discharge was measured with a SonTek FlowTracker ${ }^{\circledR}$ Handheld Acoustic Doppler Velocimeter ${ }^{\circledR}$ (ADV; model 3.5) at a point $77 \mathrm{~cm}$ upstream of the most upstream end of the screen frame using the protocol of Gallagher and Stevenson (1999). Once this initial discharge was set, we used the ADV to measure AV and SV at selected evenly spaced points across the entire screen face. We measured water velocities in triplicate at 20,40, and 60 percent water depth at nine stations across the face of the screen for a total of 27 mean velocity measurements per screen configuration (figs. 2 and 3). All AVs and SVs were measured $7.6 \mathrm{~cm}$ from the screen face and we iteratively adjusted the baffles to achieve our target velocity values. After this, we re-measured the total discharge and used this value as the test condition. Again, for all tests, about 92 percent of the discharge passed through the screen and about 8 percent was directed into the bypass.

For each trial, a single fish was released $30 \mathrm{~cm}$ below the water surface through a $7.6-\mathrm{cm}-$ diameter PVC tube with a $45^{\circ}$ fitting on the end positioned parallel to the screen and inserted immediately upstream and next to the screen face (fig. 1). We biased the release location next to the screen because pilot tests showed that most fish released in the middle of the flume a couple of meters upstream of the screen did not encounter the screen or bypass. We monitored fish real-time during the trial, measuring time to passage into the bypass or entrainment. Passage was monitored with two submerged GoPro Hero 3 cameras positioned to capture the entire length of screen with some overlap. We recorded video of each fish and reviewed it for number and duration of impingements (that is, fish getting stuck on the screen for $1 \mathrm{~s}$ or longer) and to confirm passage or entrainment time. For the trials with PP, the flume was filled with water from the Little White Salmon River. However, water turbidity prevented us from capturing usable video footage for 39 of the 64 fish tested. For these 39 fish, we determined entrainment or bypass visually during the trials but could not determine time to entrainment or bypass or number and duration of impingements. All future trials were done with well water instead of river water to prevent complications from water turbidity. Water temperatures in the flume during trials were within $2{ }^{\circ} \mathrm{C}$ of water temperatures in the holding tanks. Fish were held overnight after a trial and checked for survival the following day.

We used one-way ANOVA to test for differences in fish lengths and for differences between time to bypass or time to entrainment between screen types. To test time to bypass versus time to entrainment for individual screen types, we used t-tests with Welch's correction. T-tests and ANOVAs were done with GraphPad Prism software (GraphPad Software, La Jolla, California), and the level of significance for these tests was 0.05 . We used logistic regression to estimate the probability of a fish becoming entrained relative to its length and tested the fit of the logistic regression equation to our data using the likelihood ratio test (LRT; SigmaPlot Software, Version 12.0, San Jose, California). 


\section{Perforated plate}
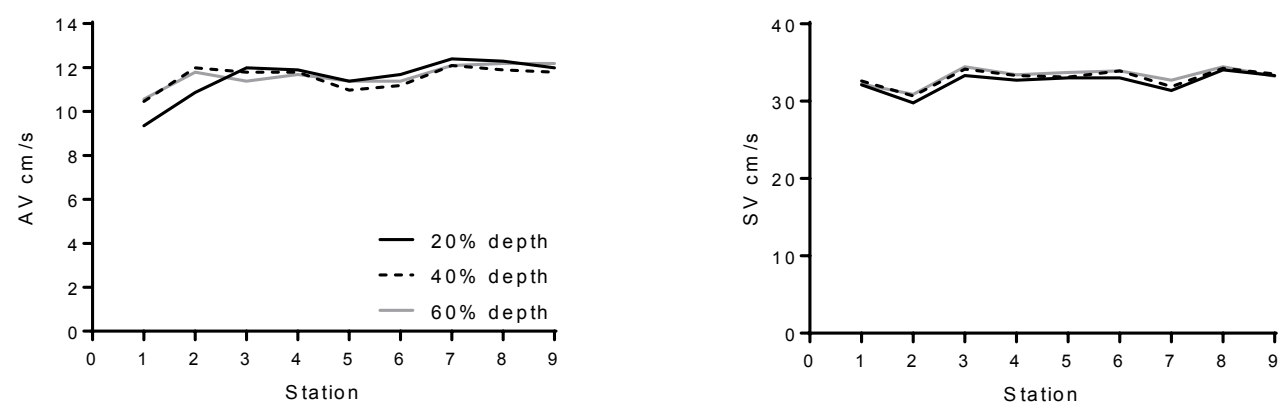

In tralox
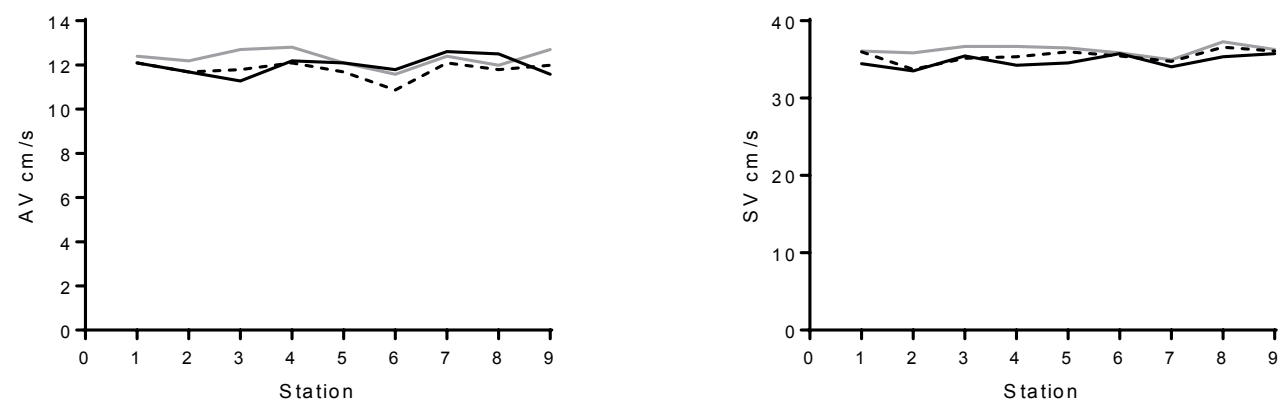

Woven wire
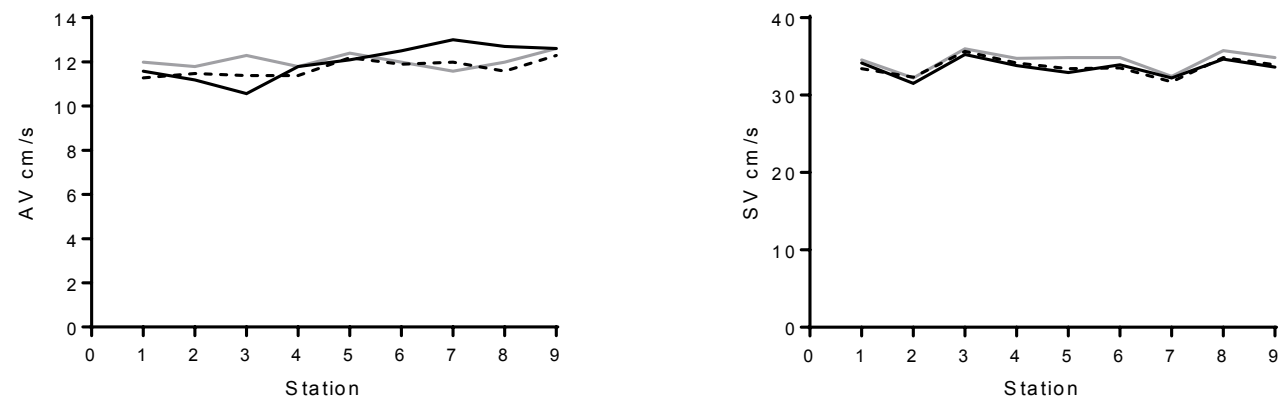

Profile bar
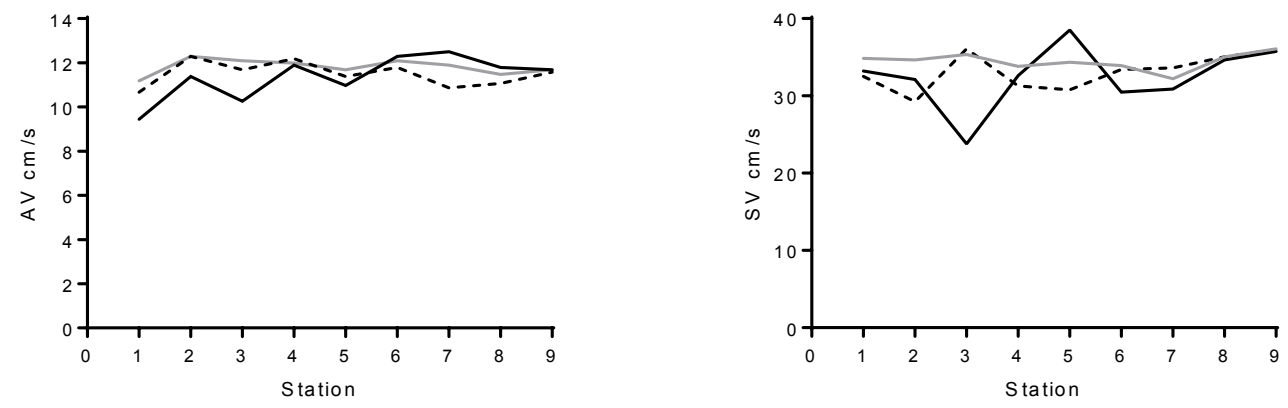

Figure 2. Approach velocity and sweeping velocity measurements for four screen types at three water depths for a target AV of 12 centimeters per second. The black line represents velocity at 20 percent of water depth, the dashed line at 40 percent water depth, and the gray line at 60 percent water depth. 
Perforated plate
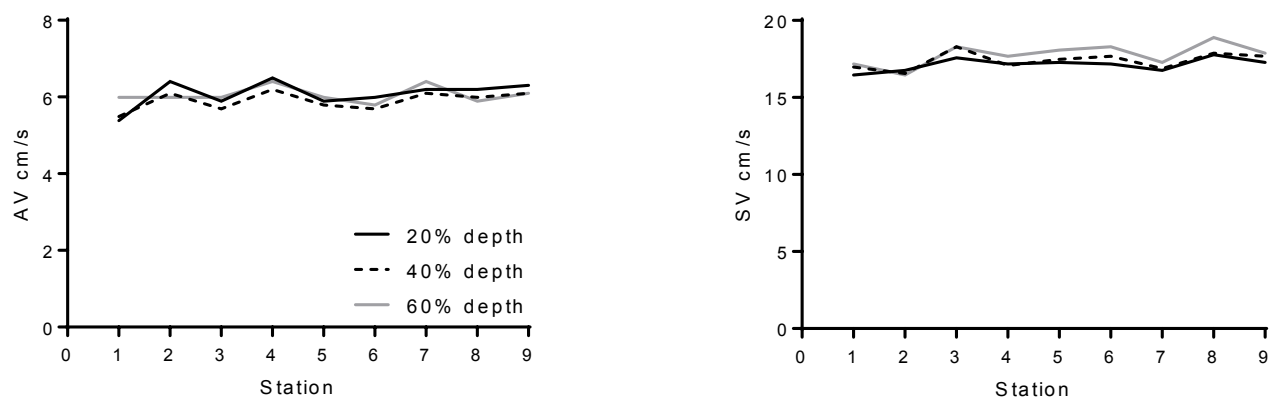

In tralox
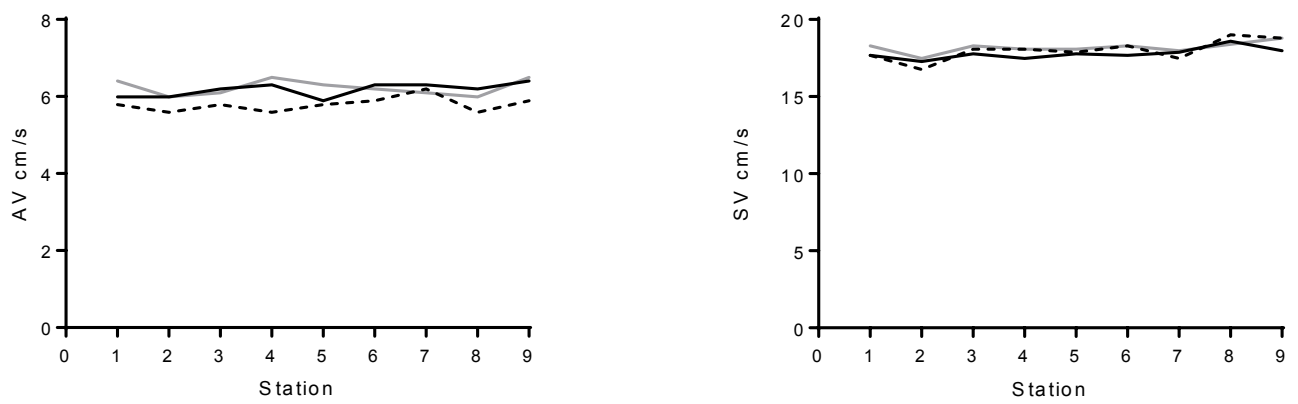

Woven wire
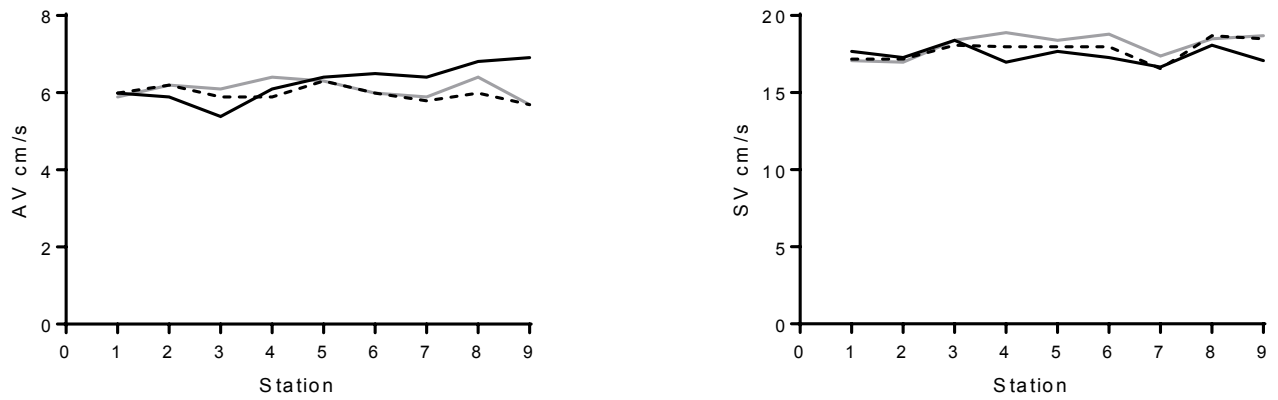

Profile bar
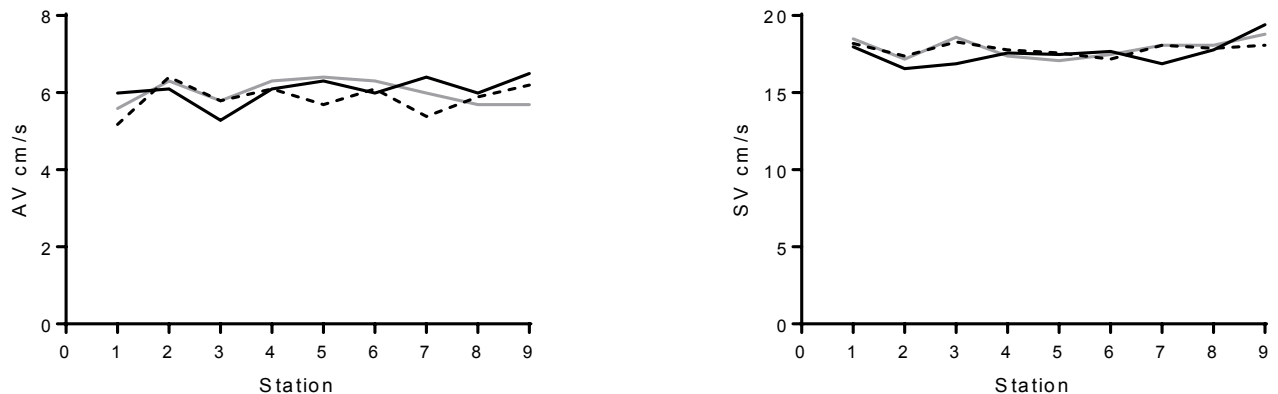

Figure 3. Approach velocity (AV) and sweeping velocity measurements for four screen types at three water depths for a target $\mathrm{AV}$ of 6 centimeters per second. The black line represents velocity at 20 percent of water depth, the dashed line at 40 percent water depth, and the gray line at 60 percent water depth. 


\section{Results}

We tested lamprey ammocoetes ranging in size from 26- to $115-\mathrm{mm}-$ long (table 1, fig. 4). The number (23-64) and mean length (45-71 mm) of lampreys tested for each screen material varied. More fish were tested at the salmonid-fry criteria AV of $12 \mathrm{~cm} / \mathrm{s}$ (46-64 fish per screen material) than at a reduced AV of $6 \mathrm{~cm} / \mathrm{s}$ (23-28 per screen material). For each screen material, we increased the number of lampreys tested in the size range where entrainment was observed during early testing, allowing us to more precisely identify the entrainment probability values for each screen (table 1, fig. 4). This resulted in statistically significant differences between lengths of fish exposed to the four different screen types at an AV of $12 \mathrm{~cm} / \mathrm{s}($ ANOVA: $F=4.26 ; \mathrm{df}=3,203 ; P=0.006)$ and at an AV $6 \mathrm{~cm} / \mathrm{s}(\mathrm{ANOVA}: F=$ 3.94; $\mathrm{df}=3,102 ; P=0.011$; table 1).

After release, fish experienced one of the following three scenarios: (1) they were entrained behind the screen; (2) they successfully moved along the full length of the screen and into the bypass; or (3) they swam away from the screen at some point along the screen face and were removed from the flume upstream of the screen or were eventually bypassed while swimming along the flume wall opposite the screen. The frequency of each of these scenarios varied depending on test conditions (fig. 5). At an AV of $12 \mathrm{~cm} / \mathrm{s}$ and an SV of $35 \mathrm{~cm} / \mathrm{s}$, it was rare for a fish to swim away from the screen except for the WW material, which had the largest open area resulting in lower focal velocities at each opening. At the reduced AV of $6 \mathrm{~cm} / \mathrm{s}$, fish swimming away from the screen was more common. Generally, fish were better able to navigate screens under their own control at the lower AV compared to the higher AV as evidenced by an increased number of fish swimming away from the screen and fewer impingements (table 2, fig. 5). At an AV of $12 \mathrm{~cm} / \mathrm{s}$ and an SV of $35 \mathrm{~cm} / \mathrm{s}$, fish had little volitional control over their movement but were swept along by the water, often pressing up against the screen and sometimes becoming impinged. Small fish (less than about $30 \mathrm{~mm}$ ) that became entrained typically passed through the screen quickly without becoming impinged. Larger fish (more than about 30-40 $\mathrm{mm}$ ) would often be briefly impinged and then either free themselves by pressing up against the screen with their tail, or they would work their way through the screen and become entrained.

The time to bypass was significantly greater than the time to entrainment for ammocoetes exposed to IL screen, WW, and PB at an AV of $12 \mathrm{~cm} / \mathrm{s}$ (t-tests: $P \leq 0.04$, fig. 6 ). The time to bypass was also significantly greater than the time to entrainment for ammocoetes exposed to IL screen at an AV of $6 \mathrm{~cm} / \mathrm{s}$ (t-test: $P \leq 0.01$, fig. 6 ). There was no significant difference between time to bypass and time to entrainment for fish exposed to PP at either AV. We could not test results for WW or PB at an AV of $6 \mathrm{~cm} / \mathrm{s}$ because only one fish was bypassed (WW) and one fish was entrained (PB) at this AV. The time to bypass was significantly longer for PP than for any other screen type (ANOVA: $F=5.71$; $\mathrm{df}=3,88 ; P=0.001)$. There were no significant differences in time to bypass for the other three screen materials tested. Overall, lampreys that encountered the screen and were effectively moved into the bypass without swimming away from the screen (and for which we had time measurements) were in the bypass in under $60 \mathrm{~s}$ except two fish exposed to PP. For fish that swam away from the screen and were removed from the flume upstream of the screen or eventually made their way into the bypass, 14 fish took longer than $60 \mathrm{~s}$ to enter the bypass, and they included fish exposed to all four screen types. Only two of the fish, however, were being tested at the lower AV of $6 \mathrm{~cm} / \mathrm{s}$. 
Table 1. Descriptive statistics of flume hydraulic conditions and lamprey ammocoetes tested for entrainment with four screen materials.

[Velocity measurements are the mean value taken at nine stations along the screen at 60 percent water depth. AV \pm SD, approach velocity plus or minus standard deviation; $\mathbf{S V} \pm \mathbf{S D}$, sweeping velocity plus or minus standard deviation.

Abbreviations: $\mathrm{cm} / \mathrm{s}$, centimeter per second; $\mathrm{m}^{3} / \mathrm{s}$, cubic meter per second; $\mathrm{mm}$, millimeter; $\mathrm{SD}$, standard deviation]

\begin{tabular}{|c|c|c|c|c|c|c|}
\hline \multirow[b]{2}{*}{ Screen material } & \multirow[b]{2}{*}{$\begin{array}{l}A V \pm S D \\
(\mathrm{~cm} / \mathrm{s})\end{array}$} & \multirow[b]{2}{*}{$S V \pm S D$} & \multirow{2}{*}{$\begin{array}{c}\text { Total } \\
\text { discharge } \\
\left(\mathrm{m}^{3} / \mathbf{s}\right)\end{array}$} & \multicolumn{3}{|c|}{$\begin{array}{c}\text { Total length } \\
(\mathrm{mm})\end{array}$} \\
\hline & & & & $\begin{array}{l}\text { Number } \\
\text { of fish } \\
\text { tested }\end{array}$ & $\begin{array}{c}\text { Mean } \\
\text { (SD) }\end{array}$ & Range \\
\hline Perforated plate & $\begin{array}{l}11.63 \pm 0.52 \\
6.06 \pm 0.21\end{array}$ & $\begin{array}{l}33.22 \pm 1.15 \\
17.78 \pm 0.73\end{array}$ & $\begin{array}{l}0.24 \\
0.13\end{array}$ & $\begin{array}{l}64 \\
23\end{array}$ & $\begin{array}{l}60(23) \\
45(16)\end{array}$ & $\begin{array}{l}26-113 \\
28-86\end{array}$ \\
\hline Intralox & $\begin{array}{l}12.32 \pm 0.40 \\
6.23 \pm 0.20\end{array}$ & $\begin{array}{l}36.24 \pm 0.66 \\
18.19 \pm 0.36\end{array}$ & $\begin{array}{l}0.27 \\
0.13\end{array}$ & $\begin{array}{l}48 \\
27\end{array}$ & $\begin{array}{l}54(19) \\
51(20)\end{array}$ & $\begin{array}{l}28-104 \\
28-100\end{array}$ \\
\hline Woven wire & $\begin{array}{l}12.05 \pm 0.33 \\
6.10 \pm 0.25\end{array}$ & $\begin{array}{l}34.46 \pm 1.31 \\
18.12 \pm 0.76\end{array}$ & $\begin{array}{l}0.25 \\
0.12\end{array}$ & $\begin{array}{l}46 \\
28\end{array}$ & $\begin{array}{l}71(24) \\
63(21)\end{array}$ & $\begin{array}{l}32-115 \\
32-108\end{array}$ \\
\hline Profile bar & $\begin{array}{l}11.82 \pm 0.35 \\
6.01 \pm 0.32\end{array}$ & $\begin{array}{l}34.48 \pm 1.10 \\
17.90 \pm 0.65\end{array}$ & $\begin{array}{l}0.24 \\
0.12\end{array}$ & $\begin{array}{l}49 \\
28\end{array}$ & $\begin{array}{l}60(24) \\
53(17)\end{array}$ & $\begin{array}{l}29-113 \\
32-97\end{array}$ \\
\hline
\end{tabular}

Table 2. Impingement statistics for four screen materials at two approach velocities.

[Impingement rate is percentage of fish that had at least one impingement. $\mathbf{A V}, \mathbf{S V}$, approach velocity, sweeping velocity. Abbreviations: $\mathrm{cm} / \mathrm{s}$, centimeter per second, $\mathrm{s}$, seconds]

\begin{tabular}{llcc|ccc|ccc}
\hline \multirow{2}{*}{ Screen material } & $\begin{array}{c}\text { AV, sV } \\
\text { (cm/s) }\end{array}$ & \multicolumn{2}{c|}{ Number of fish } & \multicolumn{3}{c|}{ Impingements } & \multicolumn{3}{c}{ Duration (s) } \\
\cline { 2 - 10 } & Tested & Impinged & $\begin{array}{c}\text { Rate } \\
\text { (percent) }\end{array}$ & Total & $\begin{array}{c}\text { Number } \\
\text { per fish }\end{array}$ & Mean \pm SD & Median & Range \\
\hline Perforated plate & 12,35 & 25 & 18 & 72 & 35 & 1.40 & $6.9 \pm 12.7$ & 2 & $1-55$ \\
& 6,18 & 23 & 9 & 39 & 13 & 0.57 & $25.0 \pm 63.3$ & 3 & $1-234$ \\
Intralox & 12,35 & 48 & 18 & 38 & 31 & 0.65 & $2.6 \pm 2.8$ & 1 & $1-12$ \\
& 6,18 & 27 & 4 & 15 & 5 & 0.19 & $2.0 \pm 1.7$ & 1 & $1-5$ \\
Woven wire & 12,35 & 46 & 10 & 22 & 12 & 0.26 & $2.7 \pm 2.3$ & 1 & $1-7$ \\
& 6,18 & 28 & 2 & 7 & 2 & 0.07 & $11.5 \pm 10.6$ & 11.5 & $4-19$ \\
Profile bar & 12,35 & 49 & 15 & 31 & 22 & 0.45 & $2.2 \pm 2.0$ & 1 & $1-8$ \\
& 6,18 & 28 & 1 & 4 & 1 & 0.04 & $1.0 \pm 0.0$ & 1 & 1 \\
\hline
\end{tabular}




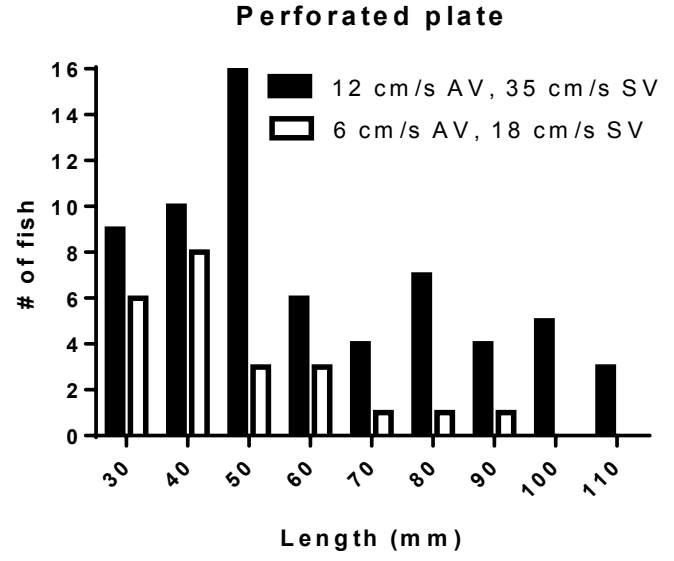

Woven wire

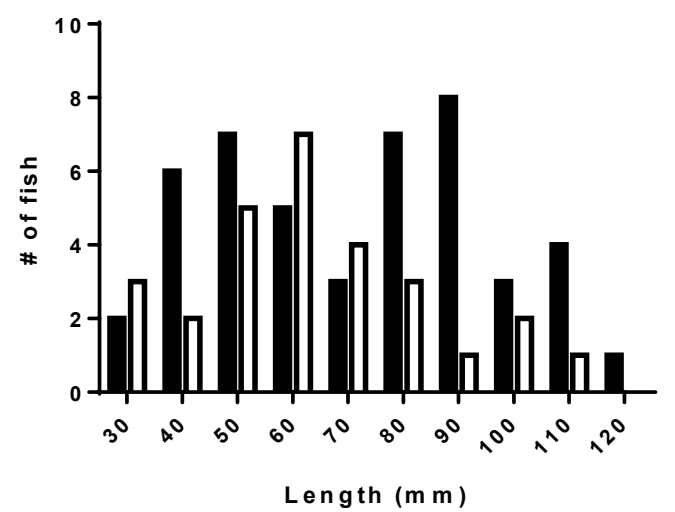

In tralox

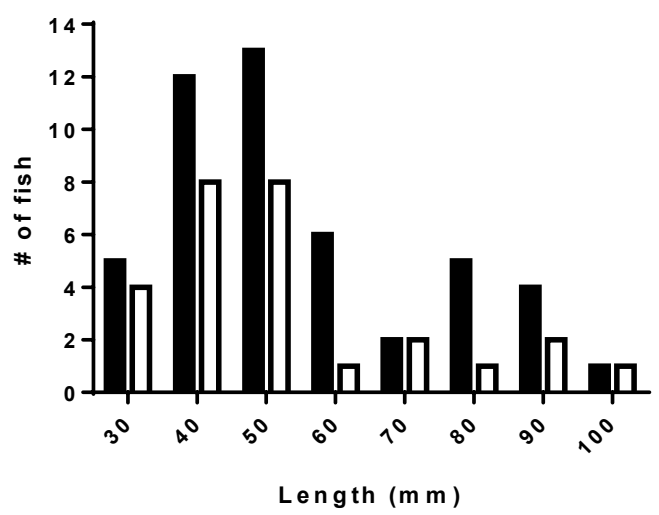

Profile bar

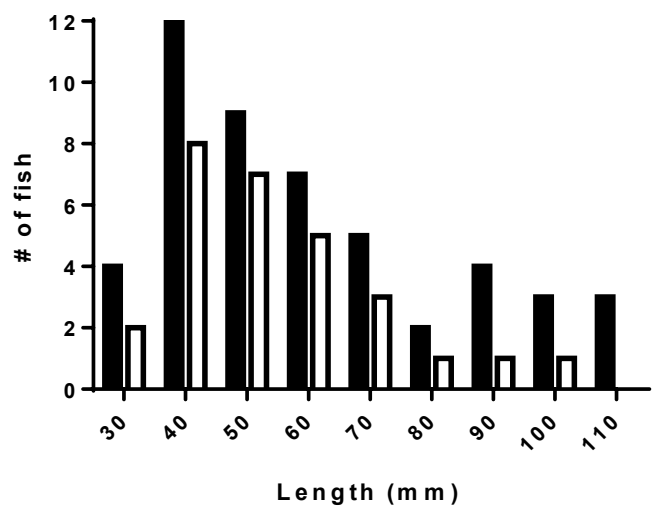

Figure 4. Length frequency distributions of lamprey ammocoetes used for entrainment and impingement tests at two approach and sweeping velocities with four screen materials. Solid bars respresent tests with 12 centimers per second $(\mathrm{cm} / \mathrm{s}$ ) approach velocity (AV) and $35 \mathrm{~cm} / \mathrm{s}$ sweeping velocity (SV). Open bars represent tests with $6 \mathrm{~cm} / \mathrm{s}$ $\mathrm{AV}$ and $18 \mathrm{~cm} / \mathrm{s} \mathrm{SV}$. mm, millimeter. 

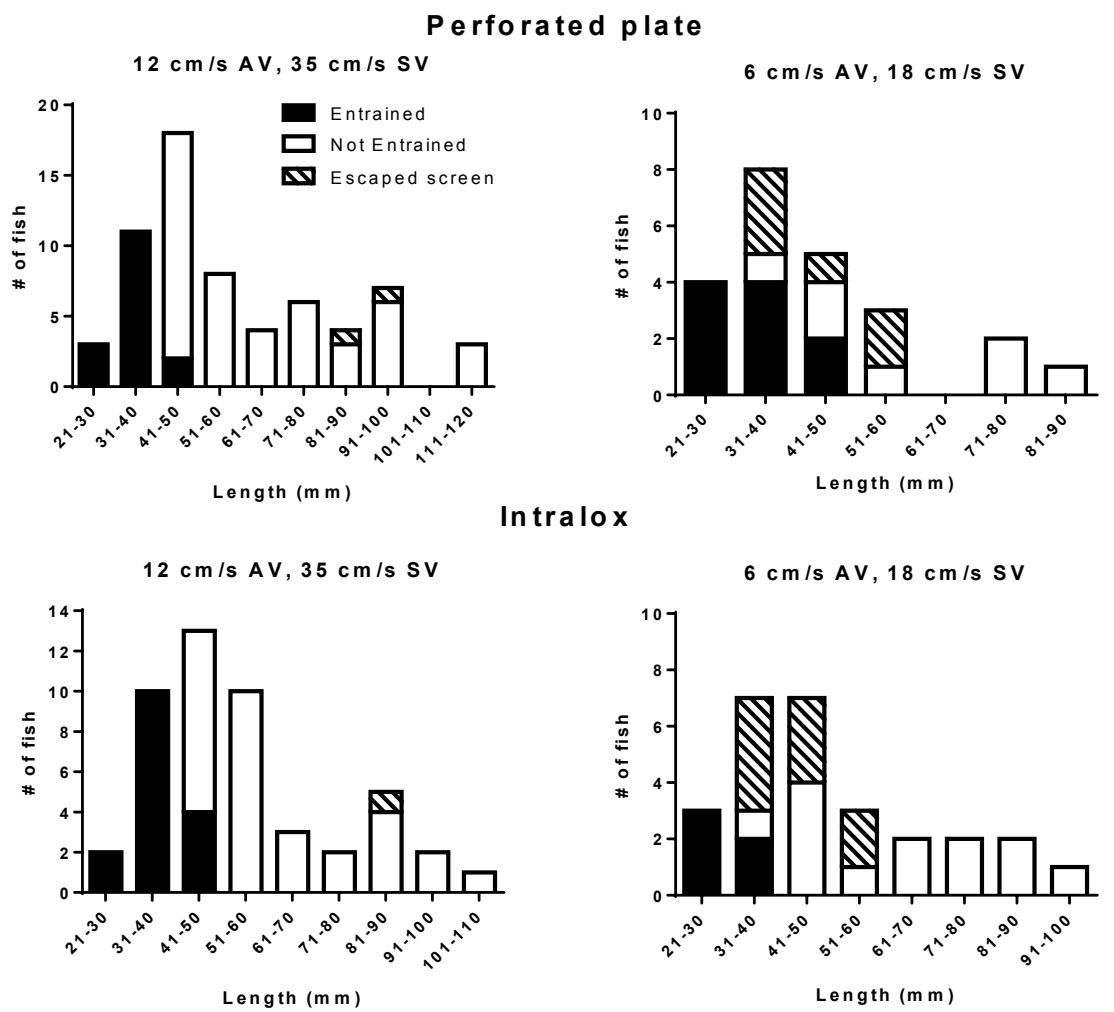

Woven wire
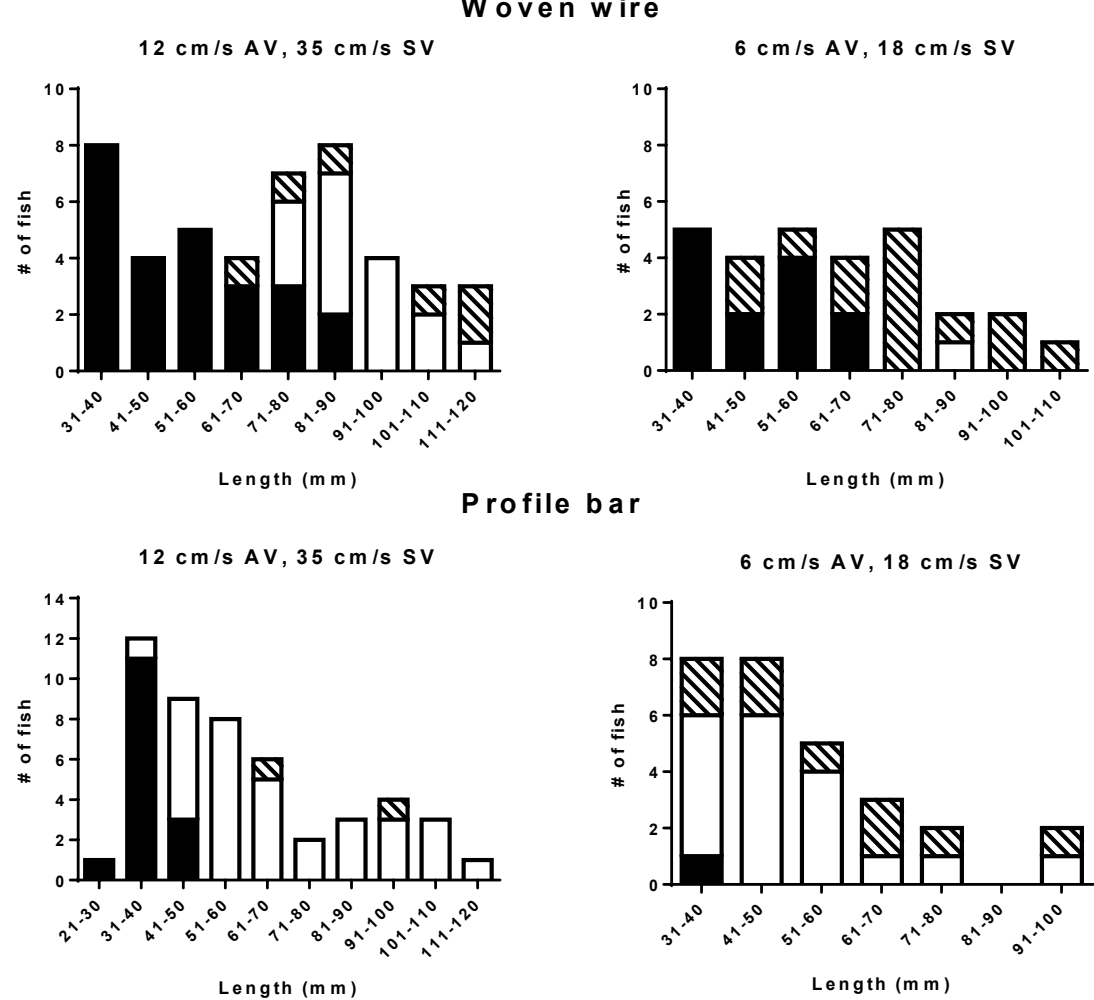

Figure 5. Number of lamprey ammocoetes that were entrained (black segment of bar), not entrained (clear segment of bar), or escaped (hashed segment of bar) from the screen surface during tests of four screen materials. $\mathrm{AV}$, approach velocity; SV, sweeping velocity; $\mathrm{cm} / \mathrm{s}$, centimeter per second; $\mathrm{mm}$, millimeter. 

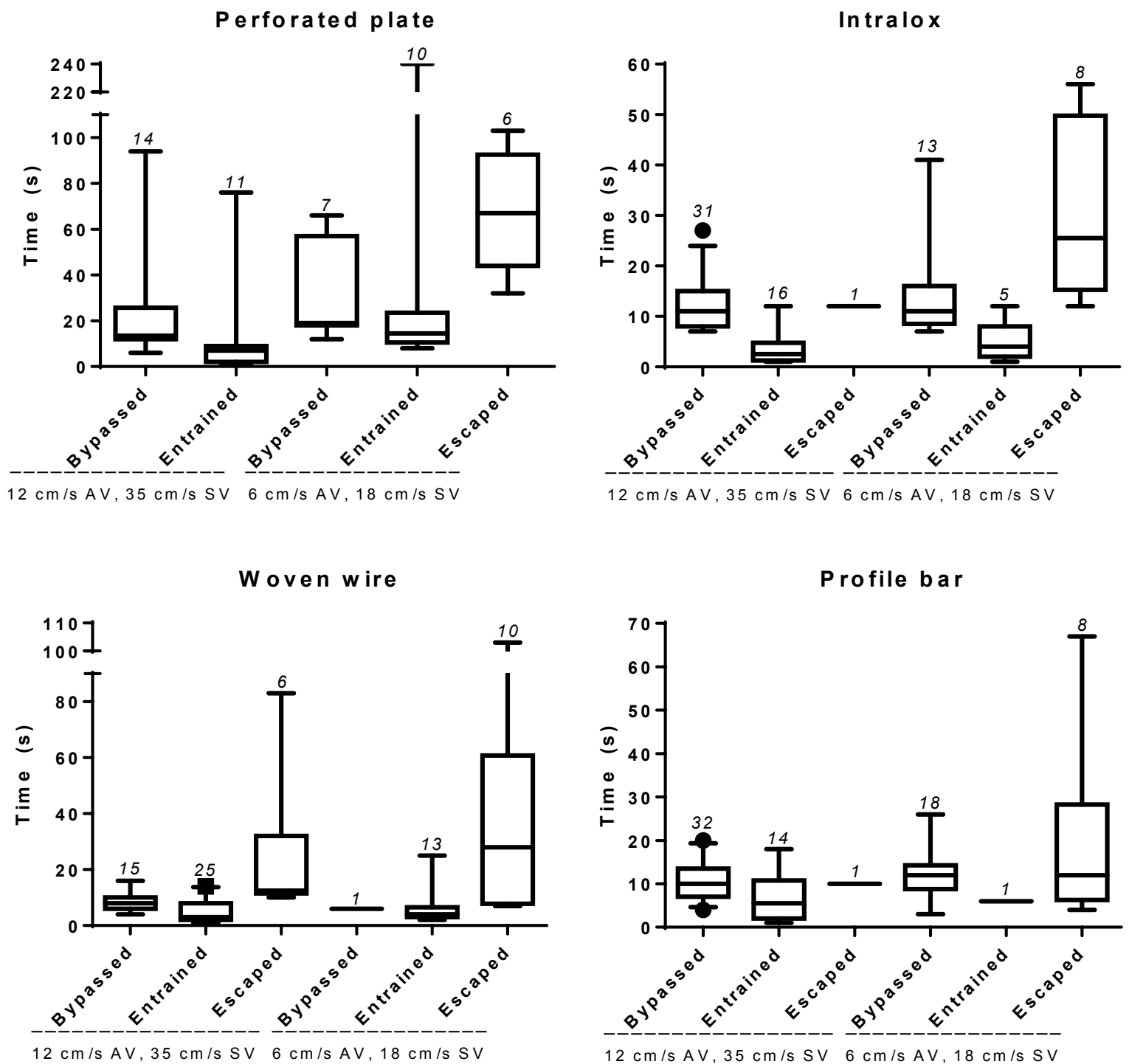

Figure 6. Amount of time it took for a fish to reach the bypass either by passing along the screen face (on screen) or swimming freely in the flume (escaped) or the amount of time it took for the fish to become entrained (entrained). The boxes represent the 25th and 75th quartiles, the whiskers represent the 5th and 95th percentiles, and the line is the median. Values above each box are the number of fish analyzed. AV, approach velocity; SV, sweeping velocity; s, second; $\mathrm{cm} / \mathrm{s}$, centimeter per second. 
Entrainment risk varied for the different screen types and was significantly affected by fish length (LRT: 15.6-59.4, $P<0.001$; table 1, figs. 7 and 8). Perforated plate protected the largest size range of ammocoetes with fish greater than about $50 \mathrm{~mm}$ having minimal entrainment risk at an AV of $12 \mathrm{~cm} / \mathrm{s}$. Intralox screen was similar, protecting fish greater than about $55 \mathrm{~mm}$ at the same AV. Twelve gauge WW protected the smallest size range of ammocoetes with fish greater than about $105 \mathrm{~mm}$ having minimal risk of entrainment at an AV of $12 \mathrm{~cm} / \mathrm{s}$. Profile bar screen, like IL, protected fish greater than $55 \mathrm{~mm}$ at an AV of $12 \mathrm{~cm} / \mathrm{s}$. For IL and WW screens, entrainment risk was slightly lower at an AV of 6 $\mathrm{cm} / \mathrm{s}$ than at an AV of $12 \mathrm{~cm} / \mathrm{s}$ (fig. 8). For PP, lowering the AV did not protect smaller fish, but fish in the size range at risk showed an increased tendency to swim away from the screen at an AV of $6 \mathrm{~cm} / \mathrm{s}$, thus avoiding entrainment (fig. 8). For PB, lowering the AV to $6 \mathrm{~cm} / \mathrm{s}$ improved screen performance since only one fish was entrained over the size range tested.

Perforated plate had the highest impingement rate (72 percent; percentage of fish that were impinged at least once) and had more impingements per fish (1.40) tested than IL (0.65) in spite of similar entrainment risk (table 2). Woven wire had the lowest impingement rate at each AV and fewest impingements per fish tested. The median impingement duration was low for all screens at both velocities (1-3 s) except for WW at an AV of $6 \mathrm{~cm} / \mathrm{s}$ because there were only two impingement events, and both were of moderate duration (table 2). Fish of all lengths were impinged and no clear patterns were observed between fish length and impingement at an AV of $12 \mathrm{~cm} / \mathrm{s}$ and an $\mathrm{SV}$ of $35 \mathrm{~cm} / \mathrm{s}$ (fig. 9). At the lower AV of $6 \mathrm{~cm} / \mathrm{s}$, only fish less than $49 \mathrm{~mm}$ were impinged on IL screen, and only fish less than $34 \mathrm{~mm}$ were impinged on WW screens (fig. 10). However, for the IL screen, we also tested more fish 28-55 $\mathrm{mm}$ than fish greater than $55 \mathrm{~mm}$.

Overall, screen exposure did not affect fish survival. Only one fish died within $24 \mathrm{~h}$ of exposure to a screen (test conditions were IL screen at an AV of $6 \mathrm{~cm} / \mathrm{s}$ and an $\mathrm{SV}$ of $18 \mathrm{~cm} / \mathrm{s}$ ). Two other fish exposed to the IL screen at an AV of $12 \mathrm{~cm} / \mathrm{s}$ and an SV of $35 \mathrm{~cm} / \mathrm{s}$ were wounded or near death $24 \mathrm{~h}$ post-trial. However, only these 3 of the 314 fish tested showed affected survival after screen exposure, and we could not eliminate a potential role for handling in these results. 


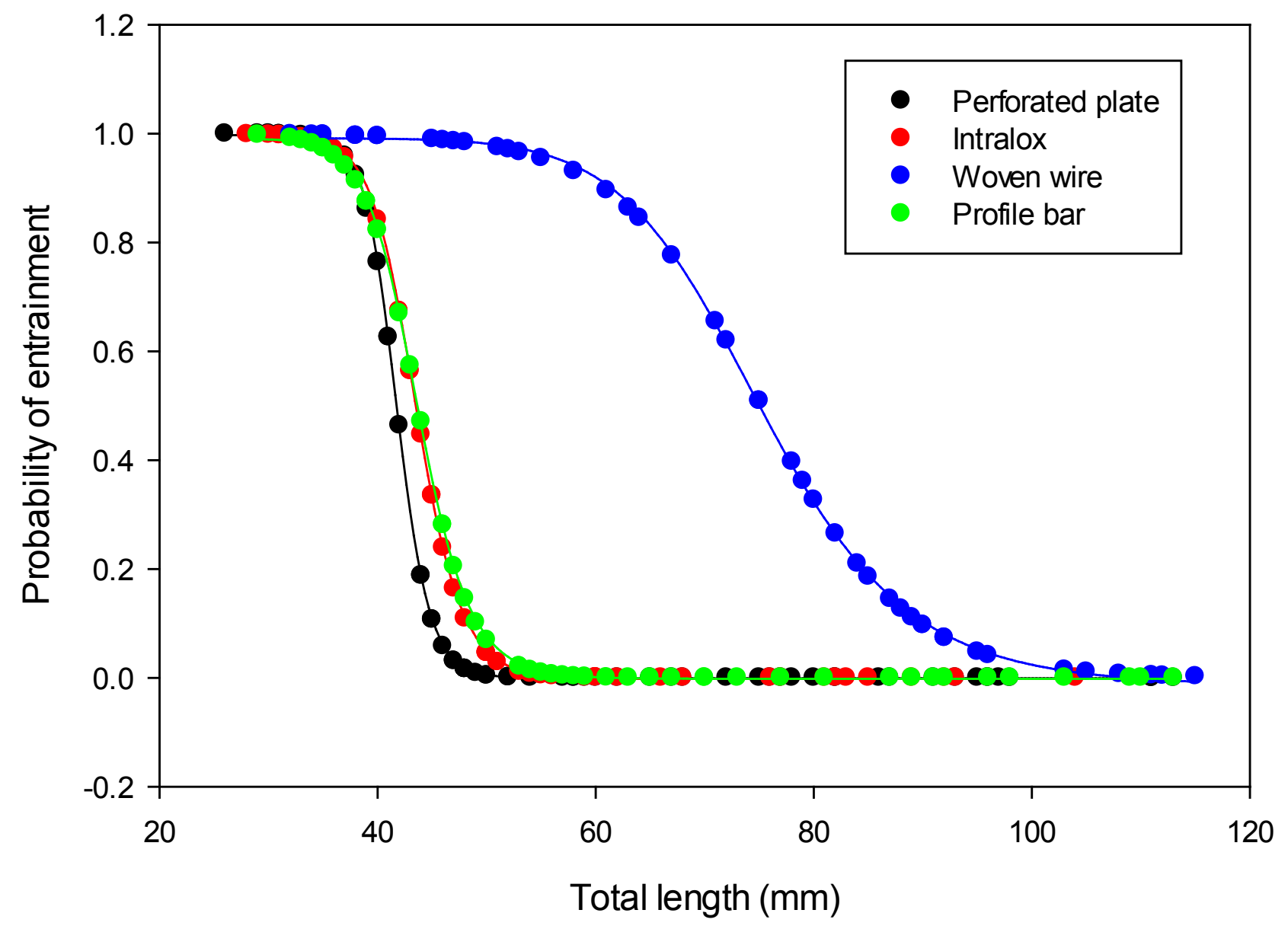

Figure 7. Logistic regression showing the entrainment probability for lamprey ammocoetes of various lengths exposed to four screen materials at an approach velocity of 12 centimeters per second and a sweeping velocity of 35 centimeters per second. $\mathrm{mm}$, millimeter. 


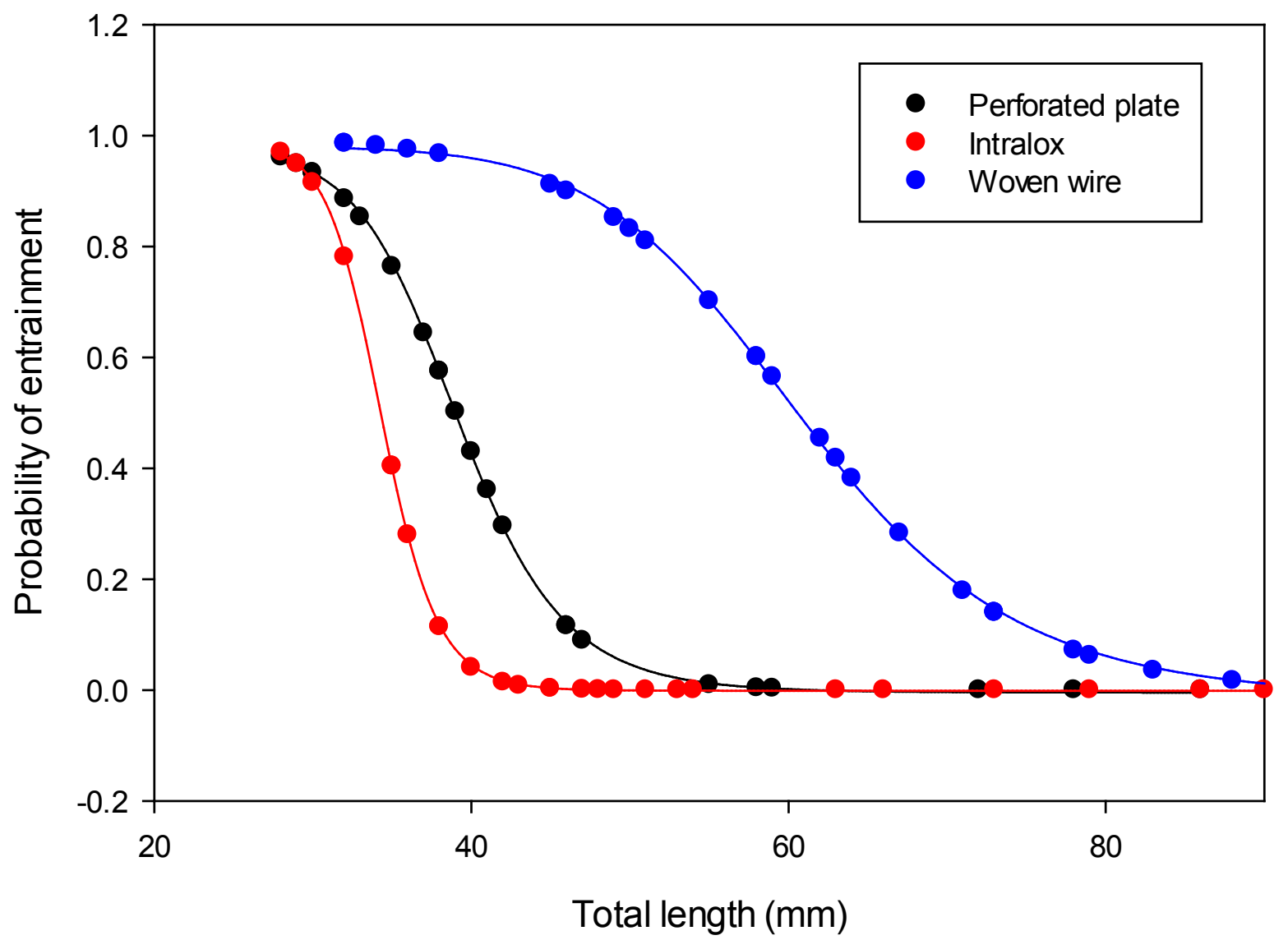

Figure 8. Logistic regression showing the entrainment probability for lamprey ammocoetes of various lengths exposed to three screen materials at an approach velocity of 6 centimeters per second and a sweeping velocity of 18 centimeters per second. $\mathrm{mm}$, millimeter. 

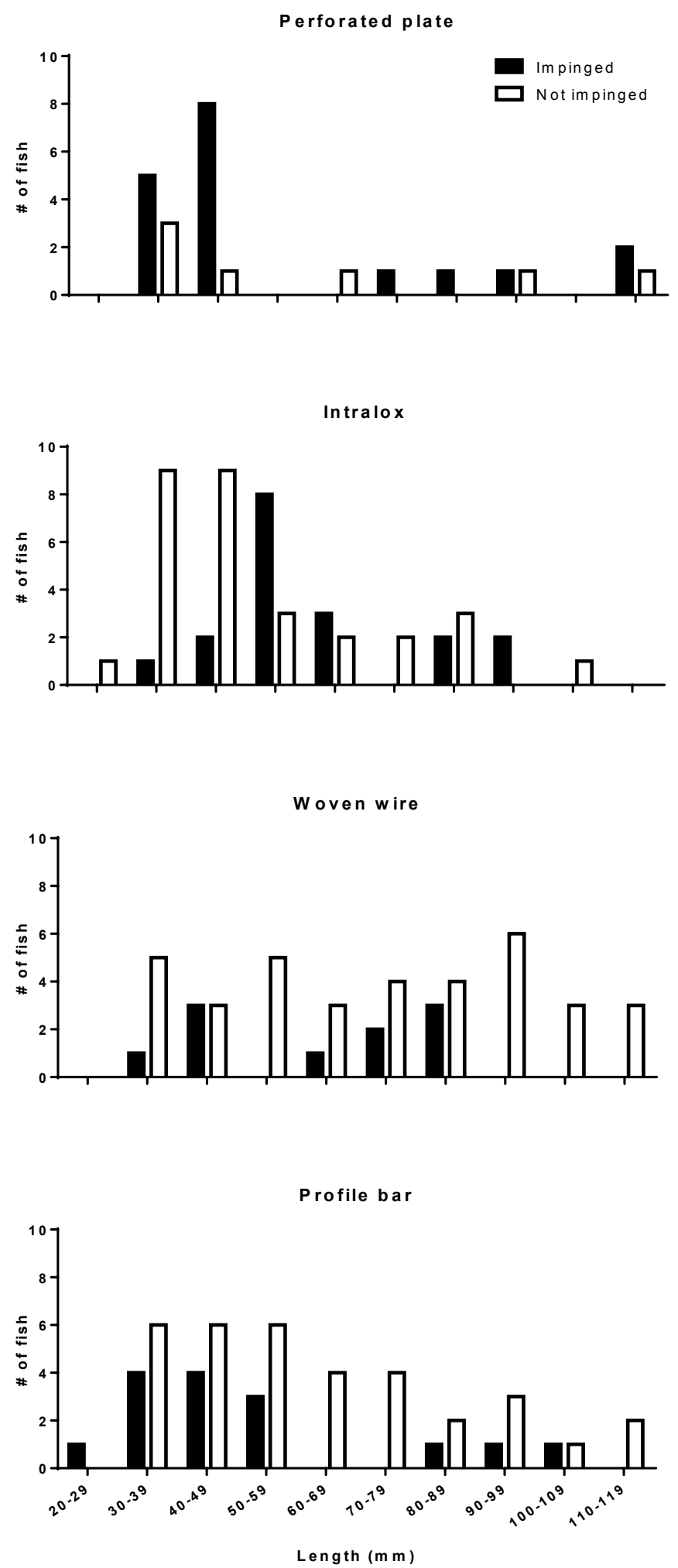

Figure 9. Length frequency distributions of ammocoetes impinged (sold bars) and not impinged (open bars) on four screen materials at an approach velocity of 12 centimeters per second and a sweeping velocity of 35 centimeters per second. mm, millimeter. 

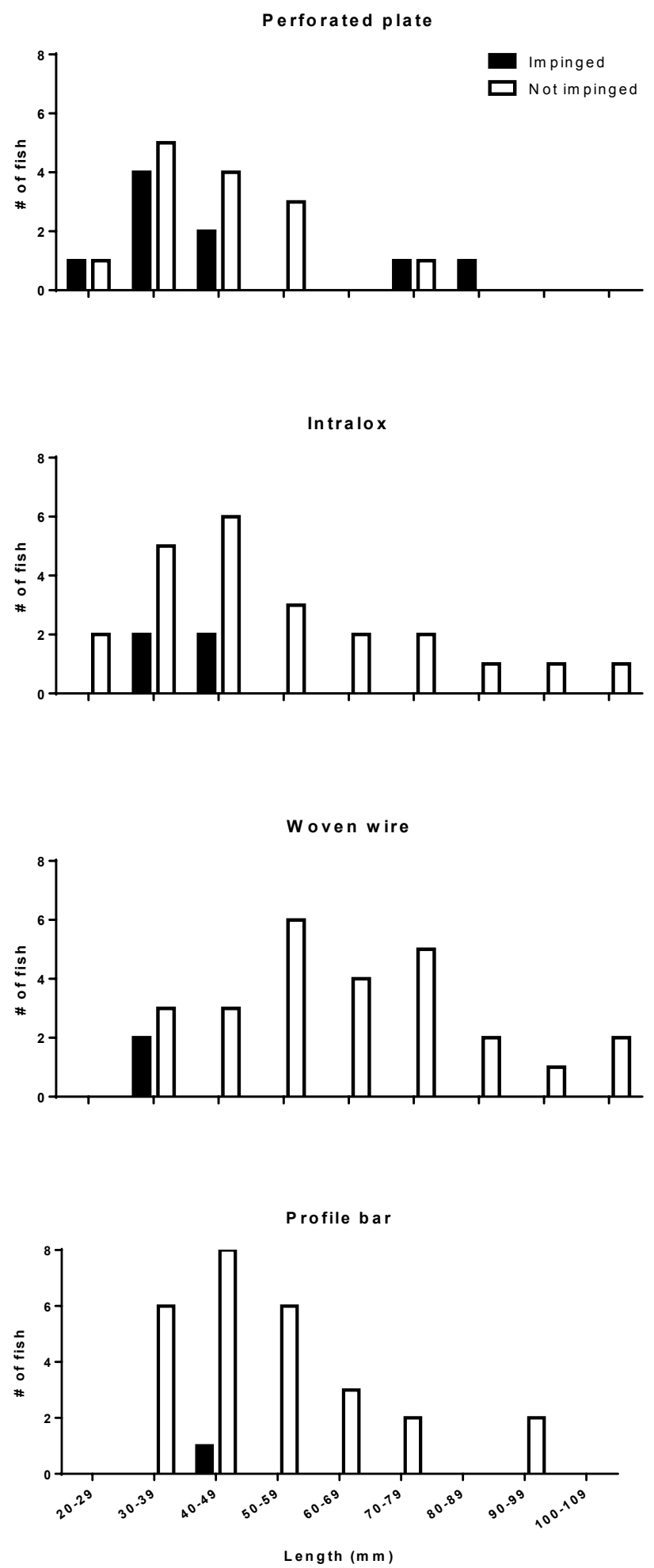

Figure 10. Length frequency distributions of ammocoetes impinged (solid bars) and not impinged (open bars) on four screen materials at an approach velocity of 6 centimeters per second and a sweeping velocity of 18 centimeters per second. mm, millimeter. 


\section{Discussion}

The addition of a SV component modestly improved protection of lamprey ammocoetes for all screen types tested, relative to previous work. A SV of $35 \mathrm{~cm} / \mathrm{s}$ with an AV of $12 \mathrm{~cm} / \mathrm{s}$ (that is, salmonid fry criteria) protected fish about 5-15 $\mathrm{mm}$ smaller than at the same AV with no SV (Rose and Mesa, 2012). However, even with this improvement, lamprey ammocoetes still had higher rates of entrainment than juveniles of other species, including Chinook salmon (Oncorhynchus tshawytscha) (Swanson and others, 2004), bull trout (Salvelinus confluentus) (Zydlewski and Johnson, 2002), delta smelt (Hypomesus transpacificus) (Swanson and others, 2005), and Pacific lamprey eyed juveniles (Ostrand, 2007). This confirms the notion of Rose and Mesa (2012) that lamprey ammocoetes, particularly small ones (approximately $<50 \mathrm{~mm}$ ), are more vulnerable to entrainment than teleosts or larger lampreys.

Overall, PP protected the smallest fish, but IL screen protected a similar size range of fish with fewer impingement events. The likely explanation for the difference in impingements between the different screen types is the percentage of open area on the screen. Current fish screening criteria require a minimum of 27 percent open area for protection of salmonid fry (National Marine Fisheries Service, 2008). Perforated plate has an open area of 27 percent, which meets the NOAA criteria. However, the other screen materials tested had open areas of 32-42 percent. We surmise that the comparatively low percentage of open area for PP resulted in higher focal velocities passing through the individual screen openings, resulting in a concomitant rise in impingements for fish of all sizes. We concur with Rose and Mesa (2012) that impingements are probably not harmful to young lampreys under most circumstances. We never saw any obvious injuries on our fish and survival was high.

At an AV of $12 \mathrm{~cm} / \mathrm{s}$, fish interacted frequently with the screens and were often impinged, especially for PP. However, the median time required for fish to pass the screens and move into the bypass was low (8-13.5 s, depending on screen type), suggesting that fish were not typically subject to long impingement events and may not be at great risk from automated cleaning devices, predation, or stress that could come from prolonged screen exposure. Moreover, lamprey ammocoetes do not have an oral disk that allows them to attach to surfaces like metamorphosed juvenile lampreys. So we did not observe prolonged, volitional attachment to the screens as occurred with metamorphosed lampreys exposed to different screen materials (Ostrand, 2007). As such, current salmonid fry screen criteria (that is, an $\mathrm{AV}$ of $12 \mathrm{~cm} / \mathrm{s}$ and an SV of about $36 \mathrm{~cm} / \mathrm{s}$ ) worked adequately for moving most lamprey ammocoetes quickly along the screen face. Many screens currently in use in field settings are larger than the screen in our experimental tank, so lamprey ammocoetes interacting with such screens may experience higher incidences of impingement events, predation, or stress than documented in this study.

After determining that addition of a sweeping velocity to an AV of $12 \mathrm{~cm} / \mathrm{s}$ made a modest improvement in protection of lamprey ammocoetes - relative to the AV alone - we considered whether decreasing the AV would improve lamprey passage. We could not test higher SV:AV ratios because of limitations in the hydraulic capabilities of our system, but we did test an AV of $6 \mathrm{~cm} / \mathrm{s}$ with a commensurately reduced SV of $18 \mathrm{~cm} / \mathrm{s}$. Although $6 \mathrm{~cm} / \mathrm{s}$ is a lower AV than would be desired at most irrigation diversions to maintain required diversion volume, we chose this velocity because it represented a large reduction that we anticipated would produce a measureable change in fish interaction with the screen. The reduced AV expanded the size range of protected lampreys by about 10-15 mm for those exposed to IL and WW screens, and it decreased protection of PP screens by about $10 \mathrm{~mm}$. Much of the improvement for IL and WW screens may be attributed to an increase in the number of lampreys swimming away from the screen. Unfortunately, movement of fish away from the screen and often back upstream is not necessarily a desirable behavior since it increases the amount of time fish spend in the passage system and provides increased opportunities for screen interactions or other adverse events, such as predation. The NOAA screening criteria specify that fish should pass the 
entire screen and move into the bypass within $60 \mathrm{~s}$ (National Marine Fisheries Service, 2008).

Generally, fish that encountered the screen and did not swim away from it met this criterion with a couple exceptions for fish exposed to PP. It is important to note that our test system is small relative to screen deployments in field settings, and fish may not be able to pass a longer screen within $60 \mathrm{~s}$. For fish that swam away from the screen, which primarily occurred at the reduced AV of $6 \mathrm{~cm} / \mathrm{s}$ and sweeping velocity of $18 \mathrm{~cm} / \mathrm{s}$, we saw increased passage times, and multiple fish exceeded the $60 \mathrm{~s}$ cutoff. These data suggest that it is important to maintain a sweeping velocity high enough that it effectively moves lampreys into the bypass and discourages movement away from the screen. Overall, our tests demonstrated that little protection was gained even by reducing the AV by half, and in the case of PP, protection was slightly decreased for larger fish, which could result from the commensurate decrease in SV. Future work should focus on exploring the effectiveness of higher SV:AV ratios in the range of 10-30:1, which are used on some horizontal flat plate screens (Mesa and others, 2012).

Finally, mortality resulting from fish interacting with the screens is likely not a concern for the screen materials we tested. Our data support findings by Rose and Mesa (2012) indicating that lamprey ammocoetes exposed to these screen materials even for extended periods of time (60 min) have high survival and experience few injuries. These data suggest that the primary concern for lamprey ammocoetes is risk of entrainment not risk of injury from the screen materials tested here.

In summary, we determined the effectiveness of four fish screen materials for protecting larval lampreys using salmonid fry-based criteria applied to a vertical screen panel. This work refined the level of protection provided by PP, IL, WW, and PB screens when both an AV and SV are present and supported our previous recommendation that 12-gauge WW screens be considered for replacement with more effective screening materials such as PP, IL, or PB (Rose and Mesa, 2012). The WW screen had larger openings than the other screen materials, which is the likely driver of its poor performance in our tests, and the rationale behind the current screen criteria (NMFS 2011) which limits screen openings to $2.38 \mathrm{~mm}$ and would therefore preclude its use at a new installation. At an AV of $12 \mathrm{~cm} / \mathrm{s}$ and an SV of $35 \mathrm{~cm} / \mathrm{s}$, our best performing screen panels (PP, IL, and PB) provided almost complete protection from entrainment for fish greater than $50 \mathrm{~mm}$. Besides vertical screens, there are many other screening devices to which ammocoetes may be exposed, including rotary drum screens, traveling belt screens, and screens with automated cleaning devices. Future work should focus on determining the risks associated with these screen types and their effectiveness in protecting lamprey ammocoetes. Also, exploring the effectiveness of higher SV:AV ratios is prudent because it may help expand the range of sizes protected by the best performing materials.

\section{Acknowledgments}

We thank Michael Lambert, Alan Ritchey, and staff from the Oregon Department of Fish and Wildlife (ODFW) for engineering and design work on the flume and logistical support; Daniel Didricksen, Kevin Fulks, Charles Lenburg, and Patrick Schille of the Washington Department of Fish and Wildlife for constructing, delivering, and setting up the flume; Ken Frisby and staff from the ODFW screen shop in The Dalles for constructing the flume baffles and logistical support; Michael Laurent of Hydrolox for donating the Intralox screen material; and Gabriel Hansen, Brien Rose, Dennis Sitherwood, and Joe Warren of the Columbia River Research Laboratory for assistance. Funding for this work was provided by Brian McIlraith of the Columbia River Intertribal Fish Commission, Susan Camp of the Bureau of Reclamation, and Gary Fredricks, Rick Martinson, and other members of the McNary Fisheries Compensation Committee. Mention of trade names does not imply endorsement by the U.S. Government. 


\section{References Cited}

Dauble, D.D., Moursund, R.A., and Bleich, M.D., 2006, Swimming behavior of juvenile Pacific lamprey (Lampetra tridentata): Environmental Biology of Fishes, v. 75, p. 167-171.

Gallagher, A.S., and Stevenson, N.J., 1999, Streamflow, in Bain, M.B., and Stevenson, N.J., eds., Aquatic habitat assessment-Common methods: Bethesda, Maryland, American Fisheries Society, $216 \mathrm{p}$.

Lampman, R.T., and Beals, T.E., 2014, A mark-release-recapture study in Congdon Diversion (Naches, Washington) to assess dispersal and entrainment of larval/juvenile lamprey: Yakama Nation Fisheries Resource Management Program, Pacific Lamprey Project, Report to Bureau of Reclamation (BOR Yakama Nation Cooperative Agreement R11AC17069), 28 p.

Lampman, R.T., Beals, T.E., Johnson, Edward, Luke, Patrick, and Lumley, Davey, 2014, Assessment of juvenile/larval lamprey entrainment in irrigation diversions and canals within the Yakima River Subbasin: Yakama Nation Fisheries Resource Management Program, Pacific Lamprey Project, Report to Bureau of Reclamation (BOR Yakama Nation Cooperative Agreement R11AC17069), 61 p.

Meeuwig, M.H., Bayer, J.M., and Seelye, J.G., 2005, Effects of temperature on survival and development of early life stage Pacific and Western brook lampreys: Transactions of the American Fisheries Society, v. 134, p. 19-27.

Mesa, M.G., Rose, B.P., and Copeland, E.S., 2012, Field-based evaluations of horizontal flat-plate fish screens, II-Testing of a unique off-stream channel device - the Farmers Screen: North American Journal of Fisheries Management, v. 32, p. 604-612.

National Marine Fisheries Service, 2008, Anadromous salmonid passage facility design: National Marine Fisheries Service, 135 p.

National Marine Fisheries Service, 2011, Anadromous salmonid passage facility design: National Marine Fisheries Service, 138 p.

Ostrand, K.G., 2007, Validation of existing screening criteria for lamprey macrophthalmia: Longview, Washington, Technical report of the Abernathy Fish Technology Center.

Rose, B.P., and Mesa, M.G., 2012, Effectiveness of common fish screen materials to protect lamprey ammocoetes: North American Journal of Fisheries Management, v. 32, p. 597-603.

Swanson, C., Young, P.S., and Cech, Jr., J.J., 2004, Swimming in two-vector flows-Performance and behavior of juvenile Chinook salmon near a simulated screened water diversion: Transactions of the American Fisheries Society, v. 133, p. 265-278.

Swanson, C., Young, P.S., and Cech, Jr., J.J., 2005, Close encounters with a fish screen-Integrating physiological and behavioral results to protect endangered species in exploited ecosystems:

Transactions of the American Fisheries Society, v. 134, p. 1111-1123.

Zydlewski, G.B., and Johnson, J.R., 2002, Response of bull trout fry to four types of water diversion screens: North American Journal of Fisheries Management, v. 22, p. 1276-1282. 

Publishing support provided by the U.S. Geological Survey

Science Publishing Network, Tacoma Publishing Service Center

For more information concerning the research in this report, contact the Director, Western Fisheries Research Center

U.S. Geological Survey

6505 NE 65th Street

Seattle, Washington 98115

https://wfrc.usgs.gov/ 
